\title{
NUMERICAL AND EXPERIMENTAL DETERMINATION OF STRESS CONCENTRATION FACTOR FOR A PIPE BRANCH MODEL
}

\author{
Darko Bajić, Nikola Momčilović, Taško Maneski, Martina Balać, Dražan Kozak, Stefan Ćulafić
}

Original scientific paper

The subject of this paper is testing of complex geometrical structures, i.e. stress analysis of a pipe branch model of A6 third pipeline at Hydropower Plant Perućica, Nikšić. Analysis of pipe branch model stress distribution was carried out by using finite element method and experimental methods. Finite element method defined 3D pipe branch model. Numerical calculation defined critical locations on model, i.e. locations with the greatest stress concentration. Strain gauges were placed on identified critical locations. Measured stress values confirmed values obtained by using numerical calculation. Experimental measurements were also taken by using new digital image correlation (DIC) method. DIC method is an optical non-contact method that can provide full 3D stress field and enables better understanding of complex structures such as pipe branches. The aim of this paper was to determine stress concentration factor for the pipe branch model by using numerical and experimental analysis.

Keywords: finite element method; pipe branch model; strain gauges; stress concentration factor; 3D DIC method

Numeričko i eksperimentalno određivanje faktora koncentracije naprezanja na modelu cijevne račve

Izvorni znanstveni članak

Predmet ovog rada je ispitivanje struktura složene geometrije, odnosno analiza naprezanja modela cijevne račve A6 trećeg cjevovoda u hidroelektrani Perućica, Nikšić. Analiza stanja naprezanja modela cijevne račve provedena je numeričkom metodom konačnih elemenata i eksperimentalnim metodama. Metodom konačnih elemenata definiran je 3D model cijevne račve. Numeričkim putem određena su kritična mjesta na modelu, odnosno mjesta najveće koncentracije naprezanja. Mjerne trake su pozicionirane na identificirane kritične zone. Izmjerene vrijednosti naprezanja metodom mjernih traka potvrdile su vrijednosti dobivene metodom konačnih elemenata. Mjerenja su provedena i uporabom 3D optičke beskontaktne metode koja se bazira na digitalnoj korelaciji slika. Tom metodom se može dobiti cjelokupno 3D polje naprezanja, odnosno ona omogućava bolje razumijevanje kompleksnih struktura kao što su cijevne račve. Cilj ovog rada je bio određivanje faktora koncentracije narezanja na modelu cijevne račve uporabom numeričkog i eksperimentalnog pristupa.

Ključne riječi: faktor koncentracije naprezanja; konačni elementi; mjerne trake; model cijevne račve; 3D DIC metoda

\section{Introduction}

Geometrical shapes of pressure equipment range from very simple (e.g. a pipe) to very complex, where geometrical complexity of the equipment produces locations with large geometrical discontinuities, resulting in stress concentration. In order to validate integrity of real structures, such as pressure vessels, pipe branches and boiler structures, with the aim of easier, subsequent monitoring of behaviour of used structures, it is necessary to perform different types of analysis dependent on the criticality, design code and load cases $[1 \div 4]$.

The subject of this paper is the analysis of stress distribution of the pipe branch model subjected to internal pressure. Pipe branches are very widely used. Pipe branch designing process requires solving many problems: pipe branch shape, choice of materials, strength calculation, cost-effectiveness and reliability. Analytical stress calculation for the pipe branch structure is possible only for cylindrical surfaces of the pipe branch, away from stiffeners and holes. The calculation is defined by pressure vessel standards. Many authors researched and analysed stress distribution of pressure vessels or pipelines, i.e. pipe branches subjected to different load types: internal pressure or combined load composed of internal pressure, axial forces and bending moments

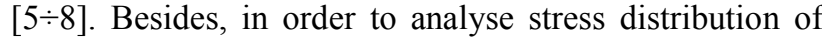
complex geometrical structures, many engineers use various software packages for calculations based on finite element method [6]. In papers [7] and [8], the authors studied limit load solutions for branch connections (with straight branch to run angles) under different loads.

In this paper, behaviour of the model of the pipe branch subjected to internal pressure was analysed both numerically and experimentally. Focus of numerical analysis was on determining critical locations, i.e. locations with the greatest stress concentration. Strain gauge method was used for measuring stresses on defined measurement locations and obtained results were very close to numerical calculations. GOM optical 3D system and ARAMIS software [9] were used for obtaining stress distribution on location with the greatest stress concentration. By comparing results with experimental method, numerical model of the pipe branch was verified.

After detailed stress analysis was done, it was possible to evaluate stress concentration factor for the pipe branch model, which can be applied on structures with similar geometry.

\section{Basic model}

For the purpose of this research, pipe branch model of complex geometry (Fig. 1) was made of steel S355J2+N. Material properties are: elasticity modulus is $210 \mathrm{GPa}$, density is $7800 \mathrm{~kg} / \mathrm{m}^{3}$ and yield stress is $355 \mathrm{MPa}$.

The pipe branch model should give the same stress value as the real pipe branch. The value of the same stress was obtained using similarity method in the following way:

$$
\sigma^{\circ}=\frac{p \cdot R}{t}=\left(\frac{\frac{p}{2} \cdot \frac{R}{5}}{\frac{t}{10}}\right)=\frac{p^{\text {model }} \cdot R^{\text {model }}}{t^{\text {model }}}
$$


$p^{\text {model }}=\frac{p}{2}, R^{\text {model }}=\frac{R}{5}, t^{\text {model }}=\frac{t}{10}$

where $p$ is internal pressure, $R$ is radius of the vessel, $t$ is thickness.

It was possible to apply similarity method to this pipe branch model subjected to internal pressure because all stresses were predominantly membrane stresses, with a very small contribution of bending stresses.

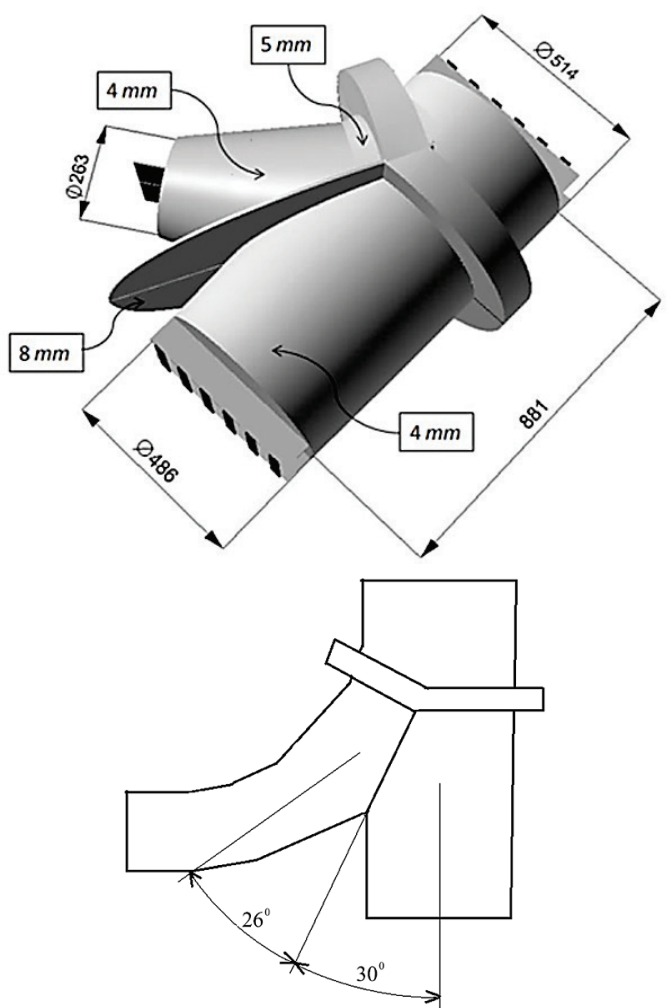

Figure 1 Pipe branch model, basic dimensions

Analytical stress calculation for the pipe branch structure is accurate only for cylindrical surfaces of the pipe branch, away from stiffeners and holes, and it is defined by pressure vessel standards. Because of very complex geometry, it was not possible to fully rely on the results of such calculation (although it gave accurate results in locations sufficiently away from discontinuities). The aim of numerical and experimental analysis was to analyse and determine pipe branch model stress distribution, i.e. to evaluate stress concentration factor in critical zones. Critical zones within the model are shown in Fig. 2 (at the cone intersection).

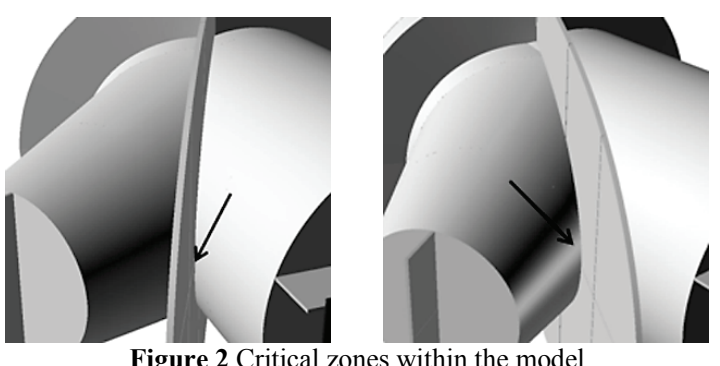

Figure 2 Critical zones within the model

\section{Finite element method}

FE model shown in Fig. 3 is made by using ABAQUS software package. Pipe branch model geometry, modelled with surfaces, was discretised into (surface) finite elements. Taking into account pipe branch symmetry regarding its geometry and load, only half of the model was analysed.
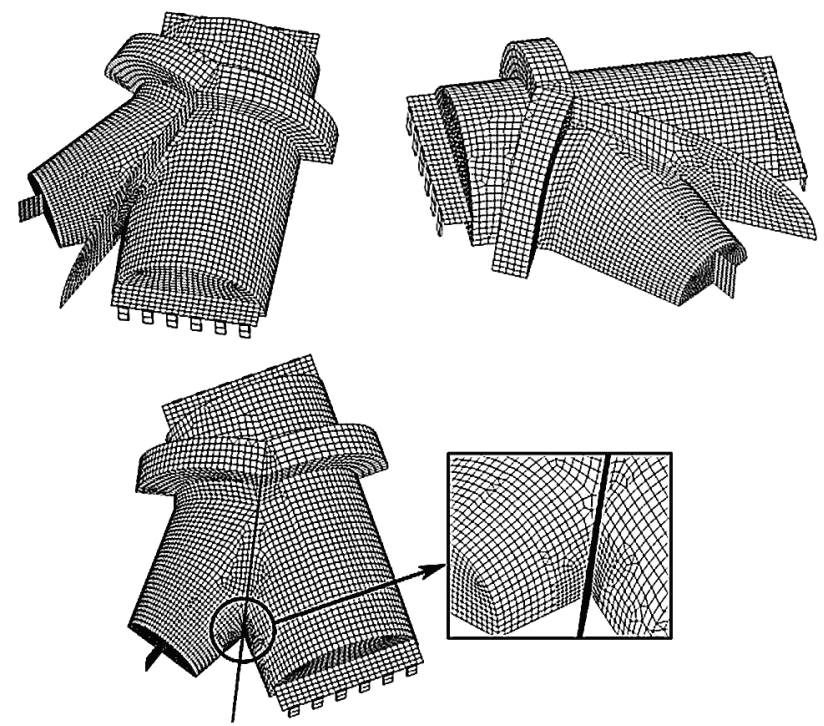

Figure 3 Finite element mesh, grid density

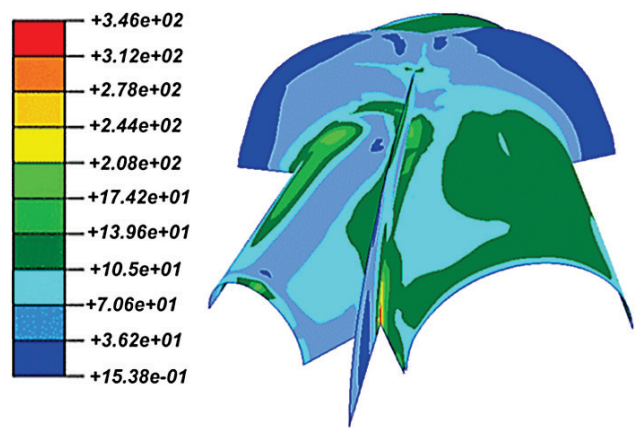

Figure 4 von Mises stresses / MPa within the model ( $p=20$ bar)
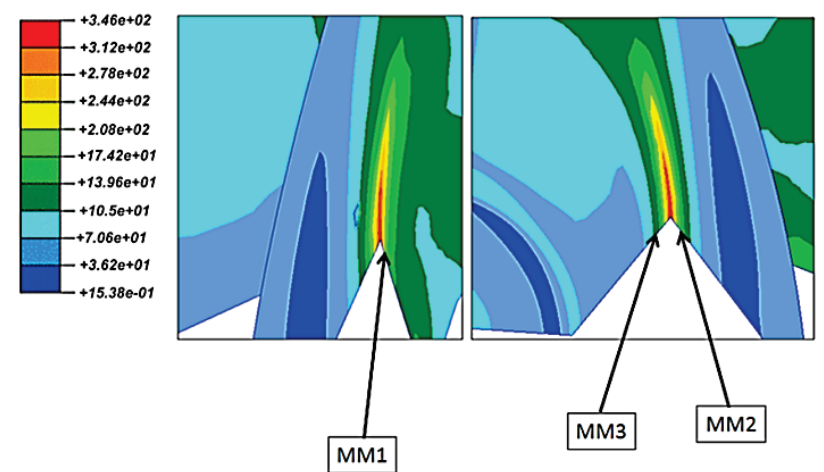

Figure 5 von Mises stresses $/ \mathrm{MPa}$ in critical zones ( $p=20$ bar)

Finite element mesh in expected critical zones of the pipe branch (based on model geometry) is denser.

Linear analysis was used for numerical calculation and the pipe branch was subjected to internal pressure with the value of 20 bar. Results of analysis obtained by using finite element method and presented in the form of von Mises stresses are shown in Figs. 4 and 5. Critical spots (measuring points MM1, MM2 and MM3) are 
marked in Fig. 5 and they present spots where strain gauge will be placed for experimental testing.

Stress values obtained on cylindrical surfaces away from discontinuities fully agree with values of calculation according to pressure vessel standards (boiler formula).

Tab. 1 shows von Mises stress values, on model, on locations with discontinuities.

Table 1 von Mises stress values on critical locations, internal pressure

\begin{tabular}{|c|c|c|c|}
\hline 20 bar & \multicolumn{4}{|c|}{} \\
\hline & MM1 & MM2 & MM3 \\
\hline von Mises stress $\sigma / \mathrm{MPa}$ & 214 & 178 & 126 \\
\hline
\end{tabular}

According to analysis of numerical calculation results, it was concluded that the maximum stress value appeared on MM1, which is the reason why only MM1 will be further analysed.

\section{Experimental analysis}

A strain gauge was placed in measuring point MM1, identified critical location with the greatest stress concentration on the structure (output of finite element method). Location on the pipe branch model where stress was measured is shown in Fig. 6.

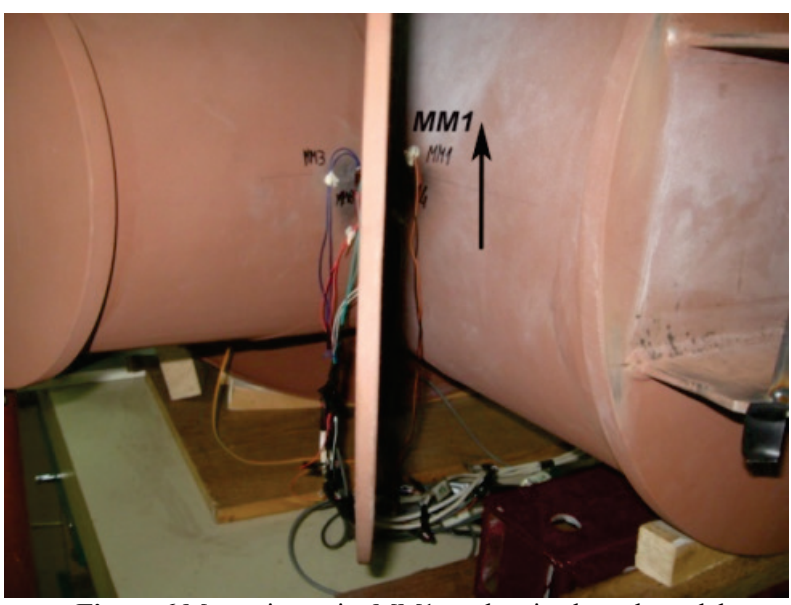

Figure 6 Measuring point MM1 on the pipe branch model

Results obtained by strain gauge in measuring point MM1 are shown in Fig. 7.

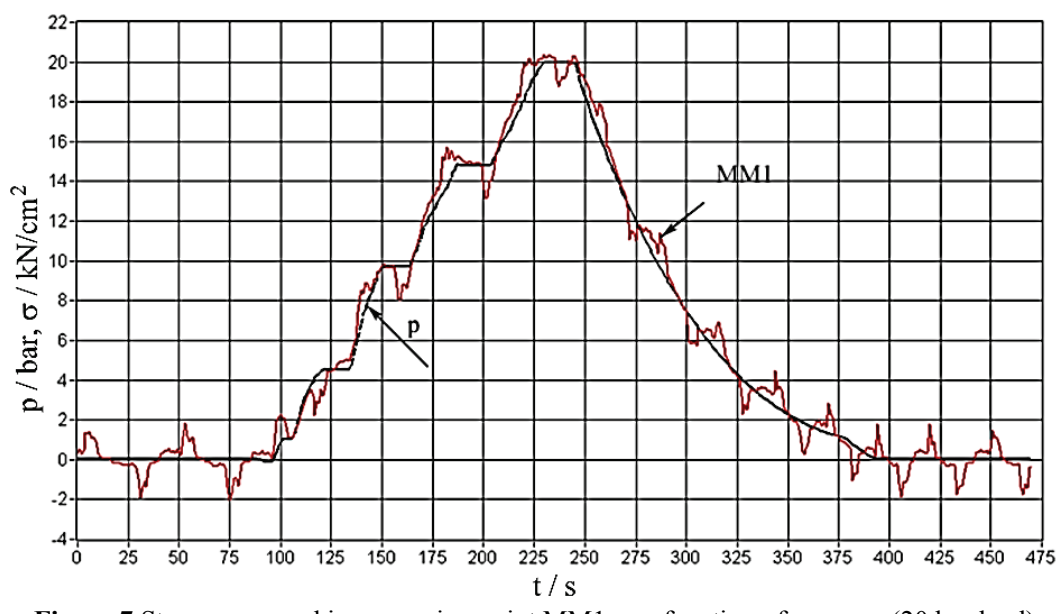

Figure 7 Stress measured in measuring point MM1 as a function of pressure (20 bar load)

Tab. 2 shows results of stress measurement performed by strain gauges and finite element method (FEM) on MM1, for 20 bar pressure load.

Table 2 Comparison of results obtained by numerical calculation and experimental measurement, measuring spot MM1, internal pressure

\begin{tabular}{|c|c|c|}
\hline \multirow{2}{*}{} & \multicolumn{2}{|c|}{20 bar } \\
\cline { 2 - 3 } & Measurement (strain gauge) & FEM \\
\hline MM1 & 205 & 214 \\
\hline
\end{tabular}

Based on numerical calculations and experimental measurements, it was concluded that MM1 was a critical location on the structure, i.e. a location with the greatest stress concentration.

After this analysis, in order to measure full strain and stress field, a fairly new experimental method for threedimensional optical strain and stress analysis, based on Digital Image Correlation (Aramis-system, Fig. 8), was used.

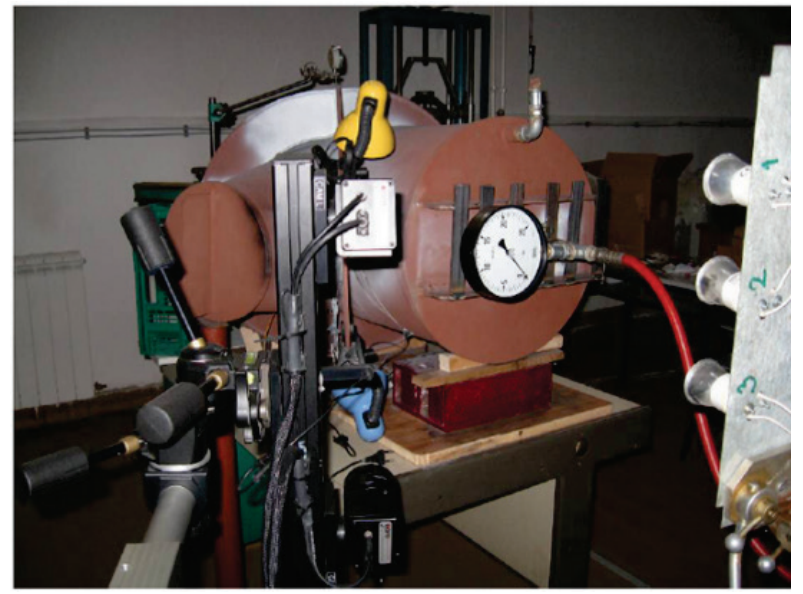

Figure 8 Experimental installation, Aramis-system

As can be calculated from Fig. 9, stress value in measuring point MM1 for 20 bar load is:

$$
\begin{aligned}
& \sigma=1100 \mu \mathrm{m} / \mathrm{m} \times 10^{-6} \times 21000=23,1 \mathrm{kN} / \mathrm{cm}^{2} \\
& \sigma=231 \mathrm{MPa} .
\end{aligned}
$$


Since it was not possible to place strain gauge on the welded joint, 3D DIC method was used for recording strain distribution on the welded joint, at the intersection of stiffener and cylinder, after what stress values were calculated (Fig. 10).
As can be calculated from Fig. 10 stress value in welded joint for 20 bar load is:

$$
\sigma=1300 \mu \mathrm{m} / \mathrm{m} \times 10^{-6} \times 21000=27,3 \mathrm{kN} / \mathrm{cm}^{2}
$$$$
\sigma=273 \mathrm{MPa} \text {. }
$$
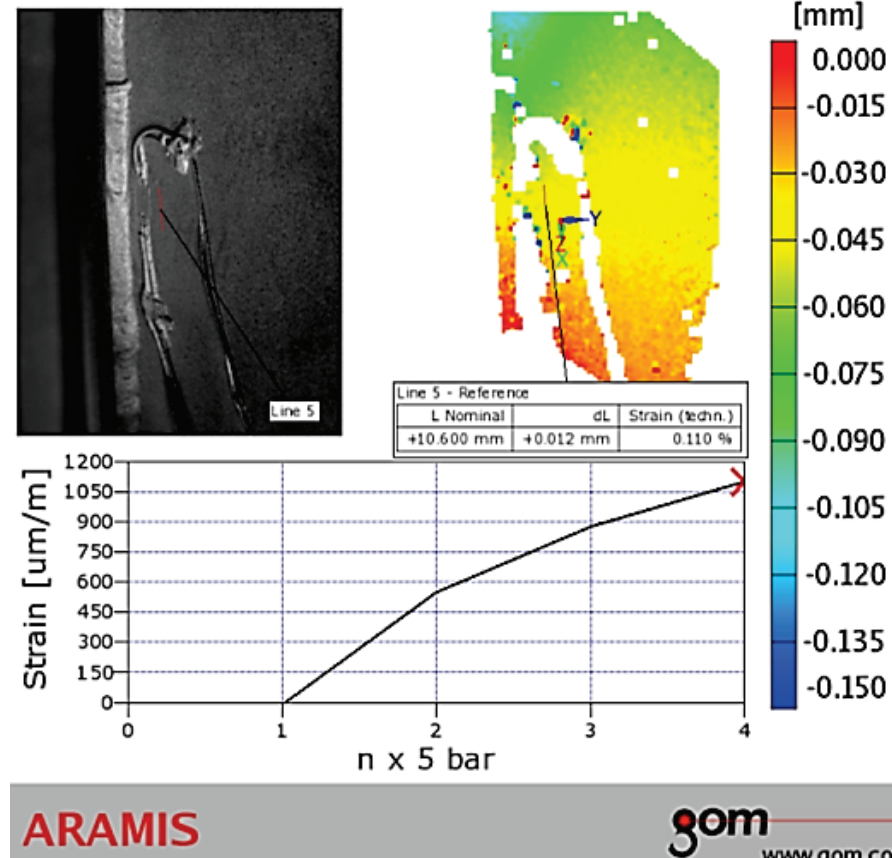

\section{3om}

www.gom.com

Figure 9 Strain field in measuring point MM1, internal pressure 20 bar
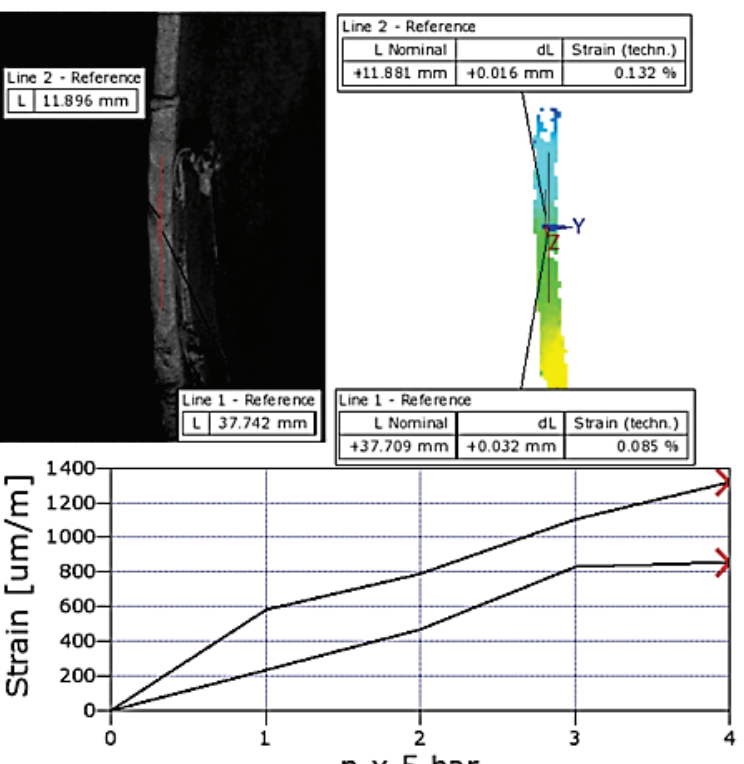

$\mathrm{n} \times 5$ bar

\section{ARAMIS}

$[\mathrm{mm}]$

0.060

0.045

0.030

0.015

0.000

$-0.015$

$-0.030$

$-0.045$

$-0.060$

Figure 10 Strain field in the welded joint, at the intersection of stiffener and cylinder, internal pressure 20 bar

Table 3 Comparison of results obtained by numerical calculation and experimental measurement, welded joint near MM1, internal pressure

20 bar

\begin{tabular}{|c|c|c|}
\hline \multirow{2}{*}{$\begin{array}{c}\text { Welded joint near } \\
\text { MM1 }\end{array}$} & Aramis-system & FEM \\
\cline { 2 - 3 } & 273 & 312 \\
\hline
\end{tabular}

Firstly, as can be seen from Fig. 5, an assessment is made that the value at the intersection of stiffener and cylinder (in welded joint) is $312 \mathrm{MPa}$, since the value averaged over small narrow areas would be even smaller.

So, since the numerical calculation cannot provide accurate stress values in areas with great geometrical discontinuity, comparing the results obtained using 3D DIC method and FEM in welded joint, estimated stress value at the intersection of stiffener and cylinder is 
$273 \mathrm{MPa}$ (for 20 bar load). That is the value obtained using 3D DIC method and it is used in further discussion.

\section{Discussion of results}

Finite element method defined the pipe branch model and numerical calculations determined critical locations on the model, thus stress distribution of the whole model was obtained. Fig. 5 shows von Mises stresses on locations with geometrical discontinuities on the pipe branch model. A strain gauge was placed on critical location MM1 (FME result). By comparing numerical and experimental results, numerical model was verified. Stress value in MM1 obtained by numerical calculation amounts to $214 \mathrm{MPa}$, whereas stress value obtained by strain gauge amounts to $205 \mathrm{MPa}$. DIC technique was used to give the full field results in MM1, as well as in the welded joint, at the intersection of stiffener and cylinder (Fig. 10), which is not possible to obtain by using strain gauges.

From Fig. 10 it can be concluded that the stress value in the basic material amounts to $231 \mathrm{MPa}$, whereas the stress value within the welded joint amounts to $273 \mathrm{MPa}$. These measurements confirm the presence of the stress concentration and it can be evaluated that the concentration intensity at the intersection of stiffener and cylinder amounts to about $30 \%$ compared to the stress measured in measuring pointMM1.

\section{Conclusion}

This paper shows stress distribution analysis of a pipe branch model of A6 third pipeline at Hydropower Plant Perućica that is subjected to internal pressure, and this paper gives the following conclusions:

- Location with the greatest stress concentration was determined by FEM (welded joint near measuring point MM1, Figs. 5 and 7).

- Numerical and experimental methods confirmed that plastic deformation would not occur on the pipe branch model when subjected to 20 bar load, which can be seen in Fig. 7, where strain gauge returned to initial stress value $(0 \mathrm{MPa})$.

- 3D optical non-contact method for full field measurement, based on digital image correlation, was applied to the pipe branch model. Fig. 9 shows stress distribution in measuring point MM1.

- Since strain gauges cannot measure stresses on the welded joint (the most critical part on the structure), it was shown that 3D DIC method could be used for obtaining full stress field in the welded joint, at the intersection of stiffener and cylinder (Fig. 10).

- Stress concentration factor was determined as a ratio between maximum stress on the location with the greatest geometrical discontinuity and value of nominal stress present on the location with regular geometry (far from the stress concentration). Since measured maximum stress value in the welded joint in MM1 amounted to $273 \mathrm{MPa}$, whereas stress value on the location far from the stress concentration amounted to $121,5 \mathrm{MPa}$, the stress concentration factor was evaluated to be 2,25 .

\section{Acknowledgements}

This article is a contribution to the Ministry of Education, Science and Technological Development of Republic of Serbia funded projects TR35040 and TR35031.

NOTE - This paper is based on the paper presented at the $7^{\text {th }}$ International Conference TEAM 2015 [10].

\section{References}

[1] Petrović, A. Stress analysis in cylindrical pressure vessels with load applied to the free end of a nozzle. // International Journal of Pressure Vessel and Piping. 78, (2001), pp. 485493. DOI: $10.1016 / S 0308-0161(01) 00062-X$

[2] Spence, J.; Nash, D. H. Milestones in pressure vessel technology. // International Journal of Pressure Vessel and Piping. 18, (2004), pp. 89-118. DOI: 10.1016/j.jpvp.2003.11.002

[3] Xue, M. D.; Du, Q. H.; Hwang, K. C.; Xiang, Z. H. An analytical method for cylindrical shells with nozzles due to internal pressure and external loads - Part 2: Design method. // Journal of Pressure vessel Technology. 132, (2010), pp. 031207-1-8. DOI: 10.1115/1.4001200

[4] Gaćeša, B.; Milošević - Mitić, V.; Maneski, T.; Kozak, D.; Sertić, J. Numerical and Experimental Strength Analysis of Fire - Tube Boiler Construction. // Technical Gazette. 18, 2(2011), pp. 237-242.

[5] Sajish, S.D.; Bhuwan Chandra Sati; Jalaldeen, S.; Selvaraj, P.; Chellapandi, P. Stress Indices for Non - Radial Branch Connections for Piping. $/ / 6^{\text {th }}$ International Conference on Creep, Fatigue, Creep - Fatigue Interaction [CF - 6], Procedia Engineering. 55, (2013), pp. 361-366.

[6] Nabhani, F.; Ladokun, T.; Askari, V. Reduction of Stresses in Cylindrical Pressure Vessel Using Finite Element Analysis. // Finite Element Analysis - From Biomedical Applications to Industrial Developments / InTech, 2012. pp. $379-390$.

[7] Kim, Y. J.; Lee, K. H.; Park, C. Y. Limit Load for Piping Branch Junctions Under Internal Pressure and In - Plane Bending - Extended Solutions. // International Journal of Pressure Vessels and Piping. 85, (2008), pp. 360-367. DOI: 10.1016/j.jppvp.2007.11.007

[8] Mkrtchyan, L.; Scha, H.; Hofer, D. Stress Indices for Branch Connections with Arbitrary Branch - To - Run Angles. // Transactions, SmiRT / New Delhi, India, 21 November 2011, pp. 1-8.

[9] www.gom.com

[10] Maneski, T.; Bajić, D.; Momčilović, N.; Mitrvić, N.; Milošević, M.; Petrović, A.; Balać, M. Analysis of the stress field in a model of pipe branches. $/ / 7^{\text {th }}$ International Scientific and Expert Conference TEAM 2015, Technique, Education, Agriculture \& Management, Belgrade, October 2015, pp. 402-405.

\section{Authors' addresses}

Dr. sc. Darko Bajić, Assistant Professor

University of Montenegro

Faculty of Mechanical Engineering

Džordža Vašingtona bb, 81000 Podgorica, Montenegro

E-mail: darko@ac.me

Dr. sc. Nikola Momčilović, Assistant Professor

University of Belgrade

Faculty of Mechanical Engineering

Kraljice Marije 16, 11000 Belgrade, Serbia

E-mail: nmomcilovic@mas.bg.ac.rs 
Dr. sc. Taško Maneski, Full Professor

University of Belgrade

Faculty of Mechanical Engineering

Kraljice Marije 16, 11000 Belgrade, Serbia

E-mail: tmaneski@mas.bg.ac.rs

Dr. sc. Martina Balać, Research Associate

University of Belgrade

Faculty of Mechanical Engineering

Kraljice Marije 16, 11000 Belgrade, Serbia

E-mail: mbalac@mas.bg.ac.rs

Dr. sc. Dražan Kozak, Full Professor

Mechanical Engineering Faculty in Slavonski Brod

Josip Juraj Strossmayer University of Osijek

Trg I. B. Mažuranić 2, HR-35000 Slavonski Brod,

Republic of Croatia

E-mail: drazan.kozak@sfsb.hr

\section{MSc. Stefan Ćulafic}

University of Montenegro

Faculty of Mechanical Engineering

Džordža Vašingtona bb, 81000 Podgorica, Montenegro

E-mail: stefanc@ac.me 